\title{
Characterization of the genetic locus responsible for production and immunity of carnobacteriocin A: the immunity gene confers cross-protection to enterocin B
}

\author{
Charles M. A. P. Franz, ${ }^{1} \dagger$ Marco J. van Belkum, ${ }^{1}$ Randy W. Worobo, ${ }^{1} \ddagger$ \\ John C. Vederas ${ }^{2}$ and Michael E. Stiles ${ }^{1}$
}

Departments of Agricultural, Food and Nutritional Science ${ }^{1}$ and Chemistry², University of Alberta, Edmonton, Alberta, Canada T6G 2P5
Author for correspondence: Michael E. Stiles. Tel: +1 780492 2386. Fax: +1 7804928914. e-mail:michael.stiles@ualberta.ca

\begin{abstract}
Carnobacteriocin A (CbnA) is a regulated bacteriocin produced by Carnobacterium piscicola LV17A that is encoded on a $72 \mathrm{~kb}$ plasmid. A $10.0 \mathrm{~kb}$ fragment from this plasmid that contained information necessary for bacteriocin production and immunity was cloned and sequenced. Genetic analysis showed the presence of the previously sequenced structural gene for CbnA, as well as genes encoding proteins homologous to dedicated bacteriocin transport proteins and proteins of three-component signal transduction systems. The induction factor ( $\mathrm{CbnX}$ ) was chemically synthesized and induced CbnA production at $10^{-11} \mathrm{M}$ or higher in a C. piscicola LV17A culture that had lost the ability to produce bacteriocin as a result of dilution. The gene cbiA for the immunity protein is not located in typical close proximity to the structural gene for CbnA and is encoded in the opposite orientation. CbiA has homology with EniB, the immunity protein for enterocin $B$ that is also encoded in the opposite orientation to the bacteriocin gene. CbiA and EniB cross-protected against the corresponding bacteriocins.
\end{abstract}

Keywords: bacteriocin, lactic acid bacteria, Carnobacterium piscicola, carnobacteriocin $\mathrm{A}$, enterocin B

\section{INTRODUCTION}

Lactic acid bacteria (LAB) produce a wide array of class II bacteriocins that have been classified by Klaenhammer (1993) and Nes et al. (1996). These are small (4-6 kDa), heat-stable peptides that are ribosomally synthesized as inactive prebacteriocins, with either an N-terminal

\footnotetext{
† Present address: Federal Research Center for Nutrition, Institute of Hygiene and Toxicology, Haid-und-Neu Strasse 9, D-76131 Karlsruhe, Germany.
}

¥Present address: Department of Food Science and Technology, New York State Agricultural Experimental Station, Cornell University, Geneva, NY 14456-0462, USA.

Abbreviations: $A B C$, ATP-binding cassette; Ap, ampicillin; ATCC American Type Culture Collection; Bac, bacteriocin production; $\mathrm{CbiA}$, carnobacteriocin A immunity protein; Cbn, carnobacteriocin; Em, erythromycin; DSM, Deutsche Sammlung von Mikroorganismen; DvnA, divergicin $A$; EniB, enterocin B immunity protein; EntB, enterocin B; LAB, lactic acid bacteria.

The GenBank/EMBL/DDBJ accession number for the sequence reported in this paper is AF207838 leader peptide that is post-translationally cleaved at a conserved Gly-Gly site, or an N-terminal signal peptide. Class IIa bacteriocins are 'Listeria-active' and contain a -YGNGVXC- amino acid motif near the N-terminus of the mature peptide. Class IIb bacteriocins consist of two peptides, for example brochocin-C (McCormick et al., 1998) and lactococcin G (Nissen Meyer et al., 1992); both peptides are required for activity. Class IIc, according to Klaenhammer (1993), contains thiolactivated bacteriocins, whereas according to Nes et al. (1996), class IIc bacteriocins are those that depend on the general secretory pathway for export of the bacteriocin from the cell. Production of class II bacteriocins, in the absence of regulatory genes, depends on at least four genes requiring $4-5 \mathrm{~kb}$ of DNA, i.e. the gene(s) for the prebacteriocin, an immunity gene, and genes for a dedicated ATP-binding cassette (ABC) transporter protein and an accessory protein (Nes et al., 1996). The bacteriocin immunity gene is usually located on the same transcription unit next to, and downstream of, the bacteriocin structural gene, and it is expressed 
with the bacteriocin gene (Nes et al., 1996). The immunity protein of class II bacteriocins protects the cell from its own bacteriocin. Despite the similarities observed for many class II bacteriocins, their immunity proteins share limited or no homology (Allison \& Klaenhammer, 1996; Aymerich et al., 1996; Nes et al., 1996; Eijsink et al., 1998).

Production of several class IIa bacteriocins is regulated by a three-component regulatory system that is homologous to signal transduction systems in bacteria (Nes et al., 1996). The components of this regulatory system consist of an induction factor, a histidine protein kinase and a response regulator (Nes et al., 1996). Production of the plantaricins S, JK and EF by Lactobacillus plantarum strains (Diep et al., 1995, 1996; Anderssen et al., 1998; Stephens et al., 1998), sakacins A and P by Lactobacillus sakei (Axelsson \& Holck, 1995; Hühne et al., 1996; Brurberg et al., 1997), carnobacteriocin B2 by Carnobacterium piscicola LV17B (Quadri et al., 1997), and enterocins $\mathrm{A}$ and $\mathrm{B}$ by Enterococcus faecium strains (Nilsen et al., 1998; O'Keeffe et al., 1999), are regulated by three-component regulatory systems.

C. piscicola LV17 produces three carnobacteriocins: A, $\mathrm{BM} 1$ and $\mathrm{B} 2$. The structural gene for carnobacteriocin BM1 (CbnBM1) is located on the chromosome and those for carnobacteriocins $\mathrm{A}(\mathrm{CbnA})$ and $\mathrm{B} 2(\mathrm{CbnB} 2)$ are located on $72 \mathrm{~kb}$ and $61 \mathrm{~kb}$ plasmids, respectively (Quadri et al., 1994; Worobo et al., 1994). By curing and plasmid mobilization the plasmids were separated and introduced into the plasmidless host strain (LV17C) as LV17A and LV17B, respectively (Ahn \& Stiles, 1992). The immunity genes for CbnBM1 and $\mathrm{CbnB} 2$ are located in an operon with the respective prebacteriocin structural genes (Quadri et al., 1994), but an immunity gene was not located in the same relative position for CbnA (Worobo et al., 1994). This was similar to the case of enterocin B (EntB) production by Ent. faecium BFE 900, where the immunity gene was not located within the same operon (Franz et al., 1999).

We previously purified CbnA and localized the gene encoding precarnobacteriocin $\mathrm{A}$ on a $1.4 \mathrm{~kb}$ cloned fragment (Worobo et al., 1994). In this study we describe the nucleotide sequence and genetic arrangement of the region downstream of the CbnA structural gene, and its relationship to immunity, dedicated bacteriocin transport and regulation of $\mathrm{CbnA}$ production. We also describe the fusion of the DNA encoding the signal peptide of the divergicin A gene to the part of the gene encoding mature CbnA, followed by the gene for CbiA. This study also reports cross-immunity between the $\mathrm{CbnA}$ and EntB immunity genes in the respective $\mathrm{CbnA}$ and EntB bacteriocin systems.

\section{METHODS}

Bacterial strains, plasmids and culture conditions. The bacterial strains and plasmids used in this study are described in Table 1. Escherichia coli strains were grown in LuriaBertani broth (LB; BBL, Becton Dickinson) at $37^{\circ} \mathrm{C}$ on a rotary shaker at 250 r.p.m. Carnobacteria were grown in APT broth (All Purpose Tween; Difco). Other LAB were grown in
Lactobacilli MRS broth (Difco) at $25^{\circ} \mathrm{C}$ without agitation. Stock cultures were prepared in the same media with $15 \%$ (v/v) glycerol and stored at $-80^{\circ} \mathrm{C}$. Antibiotics were added as selective agents when appropriate: erythromycin $(200 \mu \mathrm{g}$ $\left.\mathrm{ml}^{-1}\right)$ and ampicillin $\left(150 \mu \mathrm{g} \mathrm{ml}^{-1}\right)$ for E. coli, erythromycin $\left(5 \mu \mathrm{g} \mathrm{ml}^{-1}\right)$ or chloramphenicol $\left(10 \mu \mathrm{g} \mathrm{m}^{-1}\right)$ for LAB.

Bacteriocin activity assays. Bacteriocin activity was quantified by the critical dilution method (Franz et al., 1999), using heattreated (boiling water bath for $6 \mathrm{~min}$ ) cell-free supernatant of the producer culture. Indicator bacteria from an overnight culture were inoculated $(1 \%)$ into APT soft agar $(0.75 \%$ agar). C. piscicola LV17C was used as a sensitive indicator strain for CbnA, while L. sakei DSM 20017 was used as a sensitive indicator for both CbnA and EntB. Immunity was tested by deferred inhibition assay (Ahn \& Stiles, 1990) with C. piscicola LV17A or the EntB producer Enterococcus faecalis ATCC 19433 containing plasmid pCMAP03 (Franz et al., 1999) as producer strains, and strains containing immunity genes as indicators.

DNA manipulation, cloning and transformation. Large- and small-scale plasmid preparations from E. coli (Sambrook et al., 1989) and carnobacteria (Worobo et al., 1994; van Belkum \& Stiles, 1995) were done by established techniques. Restriction endonucleases, T4 DNA ligase and Klenow enzyme were used as recommended by the suppliers (New England Biolabs; Promega). DNA manipulations and cloning were done as described by Sambrook et al. (1989). Competent cells of E. coli were prepared and transformed according to the onestep method of Chung et al. (1989). Recombinant pMG36e plasmids were first transformed into E. coli MH1 before being transformed into LAB. Transformation of carnobacteria by electroporation was done by established methods (Worobo $e t$ al., 1995) and L. sakei DSM 20017 was transformed by the method of Berthier et al. (1996).

DNA sequence analysis. The nucleotide sequence was determined bidirectionally by Taq DyeDeoxy Cycle sequencing (Departments of Biochemistry or Biological Sciences, University of Alberta) on an Applied Biosystems 373A sequencer with stepwise deletion derivatives of cloned DNA fragments made with the Erase-a-Base system (Promega). A primerwalking strategy was used to complete small gaps in the nucleotide sequence. Synthetic oligonucleotides were made with an Applied Biosystems 391 PCR-Mate DNA synthesizer (Department of Biological Sciences, University of Alberta). Analysis of the nucleotide sequence was done with the DNA Strider (version 1.2) program. A search for homology of the predicted amino acid sequences was done with the BLAST network service at the National Center for Biotechnology Information (NCBI). Homology comparisons and calculations were done with the DNASTAR program.

Localization of the gene required for carnobacteriocin A immunity. A $10 \cdot 0 \mathrm{~kb}$ PstI fragment from pCP49 was cloned into pCaT (Jewell \& Collins-Thompson, 1989), resulting in plasmid pRW01 (Table 1). To localize the CbnA immunity gene, fragments of the $10 \cdot 0 \mathrm{~kb}$ insert in pCAT were cloned into pMG36e and certain ORFs were disrupted by using internal restriction enzyme sites. First, a $5.4 \mathrm{~kb}$ XbaI-PstI fragment was excised from pRW01, blunt-ended and cloned into the SmaI site of the lactococcal shuttle vector pMG36e (van de Guchte et al., 1989) with the CbnA structural gene in the same orientation as the P32 promoter to yield plasmid pCF01 (Fig. 1). A $3.1 \mathrm{~kb}$ Pst I-SphI fragment was excised from $\mathrm{pCF} 01$ and cloned into pMG36e resulting in plasmid pCF02. Plasmid pCF03 was created by cutting pCF02 with PstI (located in the 
Table 1. Bacterial strains and plasmids used in this study

\begin{tabular}{|c|c|c|}
\hline Bacterial strain or plasmid & Relevant characteristics* & Reference or source \\
\hline \multicolumn{3}{|l|}{ Strains } \\
\hline $\begin{array}{l}\text { Lactobacillus sakei DSM } \\
20017\end{array}$ & EntB $^{\mathrm{s}} \mathrm{CbnA}^{\mathrm{s}}$ & DSM \\
\hline Enterococcus faecium BFE 900 & ent $B^{+}$eniB $B^{+}$ent $A^{+}$, plasmidless & Franz et al. (1999) \\
\hline $\begin{array}{l}\text { Carnobacterium piscicola } \\
\text { LV17A }\end{array}$ & $c b n A^{+} c b i \mathrm{~A}^{+}$, containing $\mathrm{pCP} 49$ & $\begin{array}{l}\text { Ahn \& Stiles }(1990) \text {; } \\
\text { Worobo et al. (1994); this } \\
\text { study }\end{array}$ \\
\hline C. piscicola LV17C & $\mathrm{CbnA}^{\mathrm{s}}$, plasmidless & Ahn \& Stiles $(1990)$ \\
\hline Escherichia coli $\mathrm{DH} 5 \alpha$ & $\begin{array}{l}\mathrm{F}^{-} \text {endA1 hsdR17 }\left(\mathrm{r}_{\mathrm{k}}^{-} \mathrm{m}_{\mathrm{k}}^{+}\right) \\
\text {supE44 } \lambda^{-} \text {thi-1 recA1 gyrA96 } \\
\text { relA1 } \Delta(\operatorname{argF}-\text { lacZYA } \mathrm{U} 169 \\
\phi 80 \mathrm{~d} l a c Z \Delta \mathrm{M} 15\end{array}$ & BRL Life Technologies \\
\hline E. coli $\mathrm{MH} 1$ & $\begin{array}{l}\text { MC1061 derivative; araD139 } \\
\text { lacX74 galU galK hsr hsm } \\
\text { strA }\end{array}$ & Casadaban \& Cohen (1980) \\
\hline \multicolumn{3}{|l|}{ Plasmids } \\
\hline pUC118 & $\operatorname{lac} Z^{\prime} \mathrm{Ap}^{\mathrm{r}}, 3 \cdot 2 \mathrm{~kb}$ & Vieira \& Messing (1982) \\
\hline pMG36e & Expression vector, $\mathrm{Em}^{\mathrm{r}}, 3.6 \mathrm{~kb}$ & van de Guchte et al. (1989) \\
\hline pCP49 & $\begin{array}{l}72 \mathrm{~kb} \text { plasmid from C. piscicola } \\
\mathrm{LV} 17, c b n A^{+} c b i A^{+}\end{array}$ & Worobo et al. (1994) \\
\hline pRW19e & $\begin{array}{l}\text { pMG36e derivative containing } \\
\text { divergicin A structural and } \\
\text { immunity genes, } \mathrm{Em}^{\mathrm{r}}, 4 \cdot 1 \mathrm{~kb}\end{array}$ & $\begin{array}{l}\text { McCormick et al. (1996, } \\
\text { 1998) }\end{array}$ \\
\hline $\mathrm{pCaT}$ & $\mathrm{Cm}^{\mathrm{r}}, 8.5 \mathrm{~kb}$ & $\begin{array}{l}\text { Jewell \& Collins-Thompson } \\
\text { (1989) }\end{array}$ \\
\hline pCMAP03 & $\begin{array}{l}\text { pRW19e containing } 200 \mathrm{bp} \\
\text { HindIII-KpnI PCR product } \\
\text { insert that creates the } d v n A \\
\text { signal peptide: :entB gene } \\
\text { fusion }\end{array}$ & Franz et al. (1999) \\
\hline pCMAP05 & $\begin{array}{l}\text { pMG36e containing } 197 \mathrm{bp} \\
\text { XbaI-HindIII PCR product of } \\
\text { eniB }\end{array}$ & Franz et al. (1999) \\
\hline pRW01 & $\begin{array}{l}\mathrm{pCaT} \text { containing } 10 \cdot 0 \mathrm{~kb} \\
\text { Pst } \mathrm{I}-P \text { st } \mathrm{I} \text { fragment from } \\
\mathrm{pCP} 49\end{array}$ & Worobo (1996) \\
\hline pCF01 & $\begin{array}{l}\text { pMG36e containing } 5 \cdot 4 \mathrm{~kb} \\
\text { XbaI-Pst } \text { fragment from } \\
\text { pRW01 }\end{array}$ & This study \\
\hline pCF02 & $\begin{array}{l}\text { pMG36e containing } 3 \cdot 1 \mathrm{~kb} \\
\text { PstI-SphI fragment from } \\
\text { pCF01 }\end{array}$ & This study \\
\hline pCF03 & $\begin{array}{l}\text { pMG36e containing } 1.9 \mathrm{~kb} \\
\text { BspMI-SphI fragment from } \\
\text { pCF02 }\end{array}$ & This study \\
\hline pCF04 & $\begin{array}{l}\text { pMG36e containing } 1.4 \mathrm{~kb} \\
\text { BamHI-SphI fragment from } \\
\text { pCF02 }\end{array}$ & This study \\
\hline pCF05 & $\begin{array}{l}\text { pMG36e containing } 751 \text { bp } \\
\text { ClaI-SphI fragment from } \\
\text { pCF02 }\end{array}$ & This study \\
\hline pCF06 & $\begin{array}{l}\text { pMG36e containing } 721 \text { bp } \\
\text { BamHI-ClaI fragment from } \\
\text { pCF02 }\end{array}$ & This study \\
\hline
\end{tabular}


Table 1 (cont.)

\begin{tabular}{|c|c|c|}
\hline $\begin{array}{l}\text { Bacterial strain } \\
\text { or plasmid }\end{array}$ & Relevant characteristics* & Reference or source \\
\hline pCF07 & $\begin{array}{l}\text { pMG36e containing } 400 \text { bp } \\
\text { BamHI-HindIII fragment from pCF02 }\end{array}$ & This study \\
\hline pCF08 & $\begin{array}{l}\text { pMG36e containing } 231 \text { bp XbaI-KpnI } \\
\text { PCR product insert of } c b i A\end{array}$ & This study \\
\hline pCF09 & $\begin{array}{l}\text { pRW19e containing } 218 \text { bp HindIII-KpnI } \\
\text { PCR product insert that creates the } d v n A \\
\text { signal peptide: } c b n A \text { gene fusion }\end{array}$ & This study \\
\hline pCF10 & $\begin{array}{l}\text { pRW19e containing } 200 \text { bp } d v n A \text { signal } \\
\text { peptide: : entB PCR fusion product and } \\
197 \text { bp eniB PCR product }\end{array}$ & This study \\
\hline pCF11 & $\begin{array}{l}\text { pRW19e containing } 218 \mathrm{bp} d v n A \text { signal } \\
\text { peptide: } c b n A \text { PCR fusion product and } \\
231 \mathrm{bp} c b i A \text { PCR product }\end{array}$ & This study \\
\hline pCF12 & $\begin{array}{l}\text { pRW19e containing } 200 \text { bp } d v n A \text { signal } \\
\text { peptide: }: \text { ent } B \text { PCR fusion product and } \\
231 \text { bp cbiA PCR product }\end{array}$ & This study \\
\hline pCF13 & $\begin{array}{l}\text { pRW19e containing } 218 \mathrm{bp} d v n A \text { signal } \\
\text { peptide: }: c b n A \text { PCR fusion product and } \\
197 \text { bp eniB PCR product }\end{array}$ & This study \\
\hline
\end{tabular}

*Ap ${ }^{\mathrm{r}}$, ampicillin resistant $\mathrm{Em}^{\mathrm{r}}$, erythromycin resistant, $\mathrm{Cm}^{\mathrm{r}}$, chloramphenicol resistant.

multiple cloning site) and at a unique BspM1 restriction site located within the $3 \cdot 1 \mathrm{~kb}$ fragment. The plasmid was bluntended and self-ligated. Plasmids pCF04 to pCF07 were prepared using the same deletion technique (Table 1, Fig. 1).

Preparation of the divergicin A signal peptide::carnobacteriocin A structural gene fusion. Creation of a divergicin A $(d v n A)$ signal peptide: :ent $B$ fusion construct was previously described (Franz et al., 1999) and this construct in plasmid pCMAP03 was transformed into Ent. faecalis ATCC 19433 to produce EntB by the general secretory pathway. To create the $d v n A$ signal peptide: $: c b n A$ fusion construct the primers CF01 (5'-TAT AAA GCT TCT GCT GAC CAA ATG TCA GAT GGT GT-3') and CF-02 (5'-TAT ACT GCA GCA TGC GAG TTT TTT ATT TCA TAC AGC TA-3') were used. Primer CF-01 contained a HindIII restriction site (underlined) which, together with the next 5 nucleotides (CTGCT), encodes the carboxy terminus of the DNA encoding the DvnA signal peptide (Worobo et al., 1995; McCormick et al., 1996). The nucleotides which follow CTGCT encode the amino terminus of mature CbnA and created an in-frame fusion of the $3^{\prime}$ end of the DvnA signal peptide DNA and the CbnA structural gene. Primer CF-02 contained adjacent PstI and SphI restriction sites (underlined) and it is complementary to the 3' end of the CbnA structural gene. Using CF-01 and CF-02 as primers and pCF02 as template, DNA was amplified in $100 \mu \mathrm{l}$ in 32 cycles (denaturation, $94^{\circ} \mathrm{C}, 1 \mathrm{~min}$; annealing, $54^{\circ} \mathrm{C}$, $1 \mathrm{~min}$; extension, $72^{\circ} \mathrm{C}, 1 \mathrm{~min}$ ) using a temperature cycler (Omnigene, Intersciences). The PCR mixture contained $1.0 \mu \mathrm{M}$ of each of the respective primers, $200 \mu \mathrm{M}$ of dNTPs, 1 unit of TaqPlus Precision DNA polymerase and $1 \times$ TaqPlus Precision buffer (Stratagene). The PCR product was cloned into the PstI-HindIII sites of pUC118 for sequencing to confirm the fidelity of the reaction and for further cloning.

PCR amplification of the carnobacteriocin A and enterocin B immunity genes. eniB (the EntB immunity gene) was pre- viously amplified by PCR and cloned into plasmid pMG36e to yield pCMAP05 (Franz et al., 1999) as shown in Fig. 2. cbiA (the CbnA immunity gene) was amplified by PCR using plasmid pCF02 as template. Primers CF-03 (5'-TAT ATC TAG AGA TCT AAT CAA AAT AAC TAG GA-3') and CF-04 (5'-TAT AGG TAC CGT CTA CAG TCT GAA ACT AAA A-3') were complementary to the $5^{\prime}$ and $3^{\prime}$ ends of this gene in pCF02, and contained $X b a \mathrm{I}$ and $K p n \mathrm{I}$ restriction enzyme sites, respectively (underlined). This PCR reaction was done as described for the $\operatorname{dvnA}$ signal peptide:: $b n A$ fusion above, except that an annealing temperature of $52^{\circ} \mathrm{C}$ was used. The PCR product was cloned into pUC118 for sequencing to confirm the fidelity of the reaction. Plasmid pCF08 was created by cloning the cbiA PCR product into the XbaI-KpnI sites of pMG36e under the control of the P32 promoter (Fig. 2).

Cloning of immunity genes behind the signal peptide :: bacteriocin fusion genes and heterologous expression. The PCR amplicon that initiates the $d v n A$ signal peptide::cbnA fusion was excised from pUC118 and cloned into the HindIII and KpnI sites of pRW19e to displace the part of the $d v n A$ operon that encodes mature DvnA and the DvnA immunity protein (McCormick et al., 1996; Franz et al., 1999) to create an in-frame fusion of CbnA with the DvnA signal peptide (pCF09). Plasmid pCF10 was created by digesting pCMAP03 with $X b a \mathrm{I}$ and $K p n \mathrm{I}$ and inserting eniB (Franz et al., 1999) into these sites. $е n i B$ was originally cloned into the $X b a I$ and HindIII sites of pUC118 but was excised by digesting with $\mathrm{Xba \textrm {I }}$ and KpnI. Similarly, plasmid pCF11 was created by digesting pCF09 with $X b a \mathrm{I}$ and $K p n \mathrm{I}$ and insertion of the $c b i A$ gene. In plasmids pCF12 and pCF13 the immunity genes were exchanged (Table 1, Fig. 2). For heterologous or homologous expression of bacteriocins, plasmids pCF10 and pCF11 were 


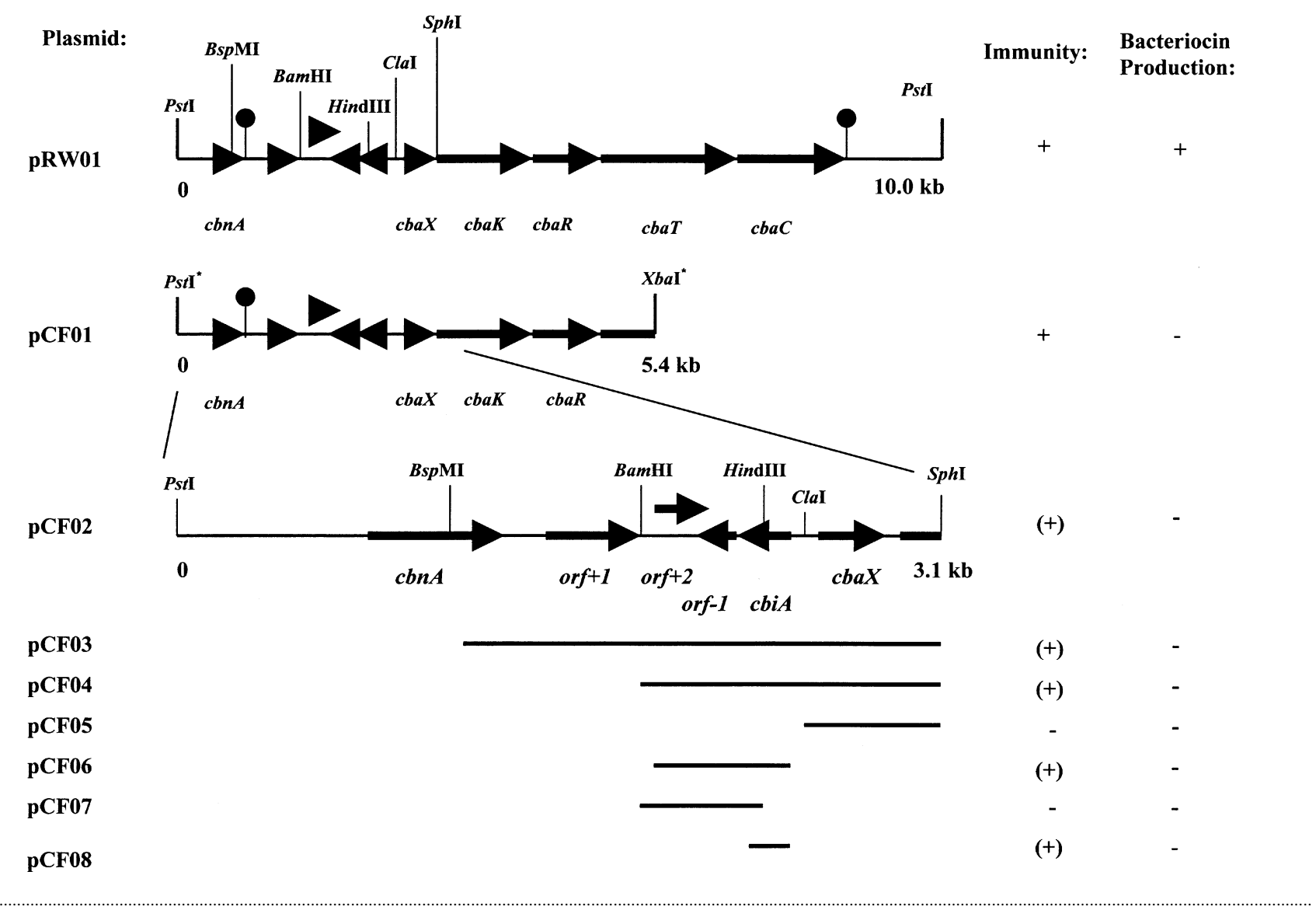

Fig. 1. Organization of genes involved in carnobacteriocin A production and immunity on plasmids pRW01 to pCF02, and schematic presentation of gene fragments in pCF03 to pCF08 to localize the carnobacteriocin A immunity gene. Bacteriocin activity and immunity of the constructs when transformed into C. piscicola LV17C is shown; $(+)$ denotes partial immunity. Stem-loop vertical lines represent transcriptional terminators.

transformed into both L. sakei DSM 20017 and C. piscicola LV17C, and bacteriocin production was determined by deferred inhibition tests with L. sakei and C. piscicola strains containing pMG36e $\left(\mathrm{Em}^{\mathrm{R}}\right)$ as indicators. For heterologous expression of immunity, L. sakei DSM 20017 containing pCMAP05 or pCF10, and C. piscicola LV17C containing pCF08 or pCF11, were used as indicators in deferred inhibition tests with Ent. faecalis ATCC 19433 containing pCMAP03 $\left(\mathrm{EntB}^{+}\right)$and C. piscicola LV17A $\left(\mathrm{CbnA}^{+}\right)$containing pMG36e as producers. To determine whether $e n i B$ and $c b i A$ could confer cross-protection against $\mathrm{CbnA}$ and EntB, pCF12 was used for heterologous expression in L. sakei and pCF13 in C. piscicola. These clones were used as indicators in deferred inhibition assays with Ent. faecalis ATCC 19433 containing pCMAP03 and C. piscicola LV17A containing pMG36e as producers, respectively.

Induction factor synthesis and induction assays. The $\mathrm{CbnA}$ induction factor (CbaX) was synthesized at Anaspec Inc. (San Jose, CA, USA) and purified to $>95 \%$ homogeneity by reverse-phase $\left(\mathrm{C}_{18}\right) \mathrm{HPLC}$ using an acetonitrile $/ \mathrm{H}_{2} \mathrm{O}$ gradient. The molecular mass of the peptide was verified by electrospray mass spectrometry. To assay for biological activity a $1 \mathrm{mM}$ stock solution of CbaX was prepared in sterile distilled water. To lose bacteriocin activity $\left(\mathrm{Bac}^{-}\right)$, a fully grown culture of $C$. piscicola LV17A was diluted $10^{6}$-fold in $5 \mathrm{ml}$ APT broth, incubated at $25^{\circ} \mathrm{C}$ and allowed to grow until turbid. Cell-free supernatant was assayed for loss of bacteriocin activity against C. piscicola LV17C. This $\mathrm{Bac}^{-}$culture was inoculated $(1 \%)$ into APT broth containing $\mathrm{CbaX}$ at concentrations ranging from $10^{-5}$ to $10^{-14} \mathrm{mM}$ and the subcultures were allowed to grow at $25^{\circ} \mathrm{C}$ for $18 \mathrm{~h}$ and tested for bacteriocin production. Cell-free supernatant $(1 \%)$ of C. piscicola LV17A containing CbnA (3200 AU ml-1) was used in an induction test as a positive control.

\section{RESULTS}

\section{Cloning and expression of the genes involved in carnobacteriocin A production}

Transformation of C. piscicola LV17C with pRW01 resulted in full production of, and immunity to, CbnA. Plasmid pCF01, containing a $5.4 \mathrm{~kb}$ XbaI-Pst I fragment from pRW01, was transformed into C. piscicola LV17C and resulted in full immunity without $\mathrm{CbnA}$ production (Fig. 1). The complete nucleotide sequence of the $10 \mathrm{~kb}$ fragment was determined. It contains the previously sequenced $1.4 \mathrm{~kb}$ fragment encoding the CbnA structural gene and orf +1 (Fig. 1), which was considered to 


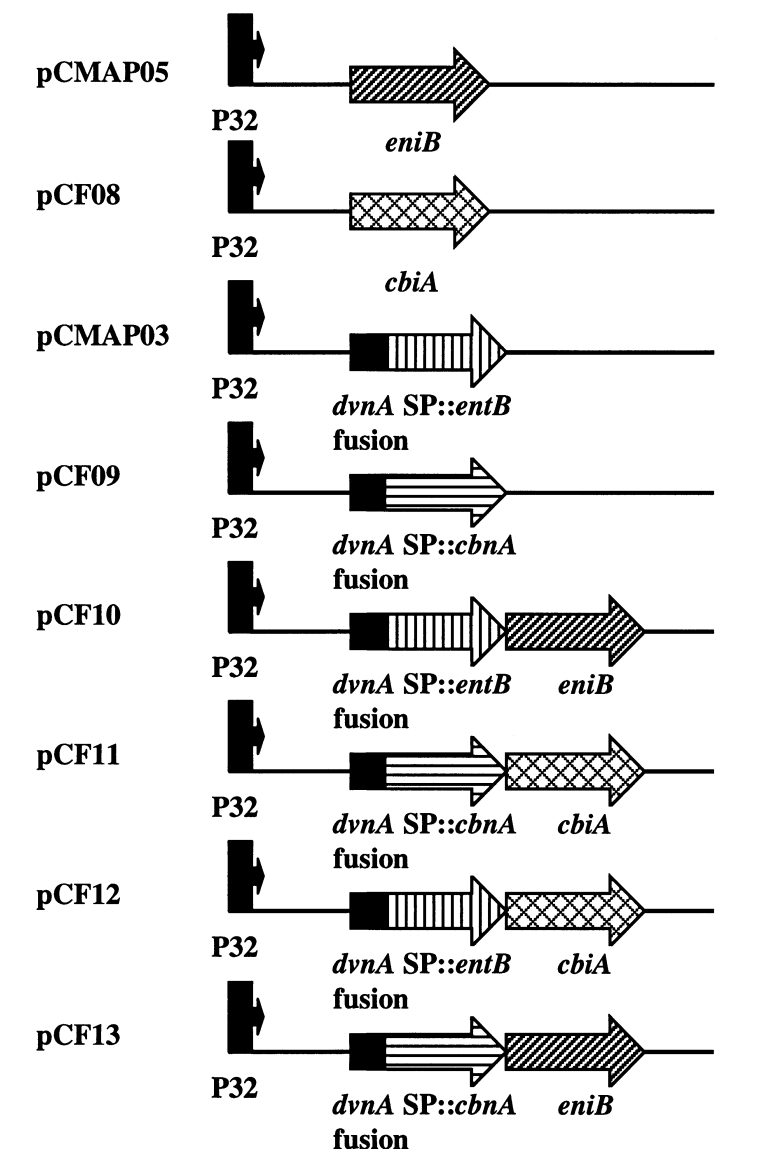

Fig. 2. Constructs used for testing production of carnobacteriocin A and enterocin B by the bacterial preprotein translocase and immunity to these respective bacteriocins. Black boxes denote the divergicin A signal peptide (dvnA SP), black boxes with an arrow indicate the P32 promoter.

be a candidate for the CbnA immunity gene (Worobo et al., 1994). Downstream of orf +1 there are three small ORFs, one of which $(o r f+2)$ could encode a protein of 73 amino acids and partially overlaps orf -1 . The other two ORFs, orf-1 and $c b i A$, are on the opposite strand, with translational products of 38 amino acids (orf- 1 ) and 56 amino acids $(c b i A)$. The products of orf +1 , orf +2 and orf -1 did not show homology to amino acid sequences reported in protein databases, while CbiA showed homology to the EntB immunity protein EniB (see below).

Downstream of these ORFs, the small ORF designated cbaX could encode a peptide of 41 amino acids. The deduced amino acid sequence of the $\mathrm{N}$-terminus (residues 1-17) of CbaX showed homology to doubleglycine-type leader peptides. Immediately downstream of $c b a X$ are two further ORFs ( $c b a K$ and $c b a R$ ) which could encode proteins of 425 and 245 amino acids, respectively. The protein products translated from $c b a X, c b a K$ and $c b a R$ revealed significant homologies to established three-component regulatory systems of class II bacteriocins. The highest homology was observed for the regulatory system involved in carnobacteriocin B2 production. The translational product of $c b a X$ showed $92 \%$ identity ( $96 \%$ similarity) to the induction factor associated with production of carnobacteriocin B2 in C. piscicola LV17B (Quadri et al., 1997). The translational products of $c b a K$ and $c b a R$ showed highest homology to the $\mathrm{CbnB} 2$ histidine protein kinase and response regulator (Table 2), as well as high homology to equivalent proteins of other regulated bacteriocins. An ORF designated $c b a T$ that could encode a protein containing 716 amino acids is located immediately downstream of $c b a R$, and it is followed by an ORF designated $c b a C$ which could encode a 455 amino acid protein. The translational products of $c b a T$ and $c b a C$ show high homology to $\mathrm{ABC}$-transporter and accessory proteins involved in the production of other class II bacteriocins. $\mathrm{CbaT}$ and $\mathrm{CbaC}$ shared highest homology with the secretion proteins of CbnB2 (Quadri et al., 1997) and they also showed homology to transporter proteins involved in secretion of EntA (Table 2).

Each of these ORFs is preceded by probable RBS. The putative promoter upstream of $c b n A$ was described by Worobo et al. (1994). A possible promoter sequence -35 (TTTAAT) and -10 (TACTTT) was found upstream of $c b a X$. Upstream of both $c b n A$ and $c b a X$ were conserved regulatory sequences consisting of right and left direct repeats. For $c b n A$ the left (TTCAGGATA) and right (TTTAGGACA) direct repeat sequences are separated by 13 bases and the right repeat sequence was located 3 bases upstream of the presumptive -35 promoter sequence. For cbaX the left (TTCAAGACT) and right (TTCAGGATG) direct repeat sequences were also separated by 13 bases and the right repeat sequence was located three bases upstream of the presumptive -35 promoter sequence. Possible rho-independent terminators were identified after the $c b n A$ and $c b a C$ genes. No other ORFs could be identified in either strand of the $10.0 \mathrm{~kb}$ PstI fragment.

\section{Induction of CbnA production with chemically synthesized, mature $\mathrm{CbaX}$}

The translation product of the putative induction factor gene cbaX contained 41 amino acids; 17 of these were assumed to be the leader peptide, terminating with the typical Gly-Gly sequence, and the following 24 amino acids constituted the possible induction factor: SINSQIGKATSSISKCVFSFFKKC. The theoretical mass of this peptide was $2610.09 \mathrm{Da}$ and the mass of the chemically synthesized CbaX determined by mass spectrometry was $2609 \cdot 26 \mathrm{Da}$, possibly indicating a disulphide bridge between $\mathrm{C}^{16}$ and $\mathrm{C}^{24}$. To determine whether the product of the cbaX gene is the induction factor for CbnA production, the chemically synthesized mature peptide was used to induce bacteriocin production in $\mathrm{a} \mathrm{Bac}^{-}$ culture of C. piscicola LV17A. When the induction factor was added at a concentration of $10^{-11} \mathrm{M}$ or higher, production of $\mathrm{CbnA}$ was induced, but not at concentrations of $10^{-12} \mathrm{M}$ or lower. Similarly, supernatant from a $\mathrm{Bac}^{+}$culture of C. piscicola LV17A used as a positive control induced bacteriocin production. 
Table 2. Homology of ORFs from the carnobacteriocin A locus to those of the carnobacteriocin B2 and enterocin A and B loci

\begin{tabular}{|c|c|c|c|c|}
\hline ORF & $\begin{array}{l}\text { Homologous } \\
\text { CbnB2 or EntA } \\
\text { protein/peptide }\end{array}$ & $\begin{array}{l}\text { Identity } \\
(\%)\end{array}$ & $\begin{array}{l}\text { Similarity } \\
\qquad(\%)\end{array}$ & Function of protein/peptide \\
\hline \multirow[t]{2}{*}{$\mathrm{CbaX}$} & $\mathrm{CbaS}$ & 92 & 96 & $\begin{array}{l}\text { CbnB2 induction factor (Quadri et al., } \\
\text { 1997) }\end{array}$ \\
\hline & EntF & 41 & 62 & $\begin{array}{l}\text { Enterocin A and B induction factor } \\
\text { (Nilsen et al., 1998; O'Keeffe et al., } \\
\text { 1999) }\end{array}$ \\
\hline \multirow[t]{2}{*}{$\mathrm{CbaR}$} & CbnR & 98 & 98 & $\begin{array}{l}\text { Carnobacteriocin B2 response regulator } \\
\text { (Quadri et al., 1997) }\end{array}$ \\
\hline & EntR & 62 & 77 & $\begin{array}{l}\text { Enterocin A response regulator } \\
\text { (O'Keeffe } \text { et al., 1999) }\end{array}$ \\
\hline \multirow[t]{2}{*}{ CbaK } & CbnK & 97 & 97 & $\begin{array}{l}\text { Carnobacteriocin B2 histidine kinase } \\
\text { (Quadri et al., 1997) }\end{array}$ \\
\hline & EntK & 38 & 62 & $\begin{array}{l}\text { Enterocin A histidine kinase (O'Keeffe } \\
\text { et al., 1999) }\end{array}$ \\
\hline \multirow[t]{2}{*}{ CbaT } & CbnT & 97 & 97 & $\begin{array}{l}\text { Carnobacteriocin B2 ABC transporter } \\
\text { (Quadri et al., 1997) }\end{array}$ \\
\hline & EntT & 72 & 84 & $\begin{array}{l}\text { Enterocin A ABC transporter (O’Keeffe } \\
\text { et al., 1999) }\end{array}$ \\
\hline \multirow[t]{2}{*}{$\mathrm{CbaC}$} & CbnC & 93 & 94 & $\begin{array}{l}\text { Carnobacteriocin B2 accessory protein } \\
\text { (Quadri et al., 1997) }\end{array}$ \\
\hline & EntD & 46 & 64 & $\begin{array}{l}\text { Enterocin A accessory protein (O'Keeffe } \\
\text { et al., 1999) }\end{array}$ \\
\hline
\end{tabular}

The $\mathrm{Bac}^{-}$culture, when inoculated into APT broth without induction factor, failed to produce bacteriocin and served as a negative control.

\section{Cloning and expression of the gene conferring immunity to carnobacteriocin $\mathbf{A}$}

pCF01 lacked $c b a C$ and the major part of $c b a T$ and failed to produce bacteriocin, but it conferred full immunity when transformed into C. piscicola LV17C (Fig. 1). The $3.1 \mathrm{~kb}$ PstI-SphI fragment in pCF02 conferred partial immunity to C. piscicola LV17C when tested against C. piscicola LV17A, indicated by a smaller zone of inhibition compared with that obtained with the sensitive C. piscicola LV17C strain. The $3 \cdot 1 \mathrm{~kb}$ fragment differed from the $5.4 \mathrm{~kb}$ fragment in that $c b n R$ and the major part of $c b n K$ were deleted (Fig. 1). Plasmid pCF03, which contains part of $\operatorname{cbnA}$ as well as orf +1 , orf +2 , orf $-1, \operatorname{cbi} A$ and $c b a X$, also conferred partial immunity to C. piscicola LV17C. Several other deletion derivatives were made (see Table 1 and Fig. 1) and cbiA was identified as the CbnA immunity gene. cbiA encodes a peptide of 56 amino acids which exhibits homology (30\% identity, $62 \%$ similarity) with EniB, the 58 amino acid immunity peptide of EntB that is produced by Ent. faecium BFE 900 (Franz et al., 1999) (Fig. 3). cbiA was amplified by PCR and cloned into the pMG36e expression vector (pCF08). cbiA in pCF08 conferred the same partial immunity phenotype as that observed for C. piscicola LV17C containing pCF02, 03, 04 or 06.
When $c b i A$ was cloned together with either the $d v n A$ signal peptide: :ent $B$ or the $d v n A$ signal peptide:: $\operatorname{cbn} A$ gene fusion in L. sakei DSM 20017, full immunity was imparted to these heterologous hosts when tested against C. piscicola LV17A in the deferred inhibition tests (see below).

\section{Expression of the divergicin A signal peptide:: bacteriocin gene fusions}

Plasmids pCF10 and 11 were constructed that encode the EntB or CbnA bacteriocins, respectively, fused to the signal peptide together with their cognate immunity protein. C. piscicola LV17C and L. sakei DSM 20017 containing plasmid pCF10 or 11 were tested for bacteriocin production against the indicators $L$. sakei DSM 20017 and C. piscicola LV17C. Zones of inhibition resulted when L. sakei DSM20017 was used as the indicator strain. When these constructs were tested against C. piscicola LV17C, activity resulted only from pCF11, indicating that C. piscicola LV17C is not sensitive to EntB. The EntB-producing, positive control Ent. faecalis ATCC 19433 was also not active against $C$. piscicola LV17C. The zone of inhibition produced by $L$. sakei DSM 20017 containing pCF11 was markedly smaller than that produced by C. piscicola LV17C containing this plasmid and noticeably smaller when tested against L. sakei DSM 20017 (8 vs $21 \mathrm{~mm}$, respectively) or C. piscicola LV17C (17 vs $23 \mathrm{~mm}$, respectively). The zone of inhibition produced by $C$. 
(a) CbiA: MKTNLPKEMLILFSISIF----SNLILIFLTDTIIQKVLSSLSLIILLVVVCKEVKKNSN

NL K L ::: IF NL L:::::TI: K:L :::::L:: $:$ KK $\mathrm{N}$

EniB: MNLKKNNLE-YNLCIFLAVI INLGLFIFSETILSKILLLIAIVLLVI PNFMQKKKRKNS

(b) CbnA: -DQMSDGVNYGKGSSLSKGGAKCGLGIVGGLATI PSGPLGWLAGAAGVINSCMK

EntB: ENDHRMPNELNRPNNLSKGGAKCGAAIAGGLFGI PKGPLAWAAGLANVYSKCN-

Fig. 3. Alignment of (a) the carnobacteriocin $A$ and enterocin $B$ immunity proteins (CbiA and EniB, respectively) and (b) mature carnobacteriocin A and enterocin B (CbnA and EntB, respectively) by Lipman-Pearson alignment. Identical amino acids are shown; similar amino acids are indicated by a colon sign.

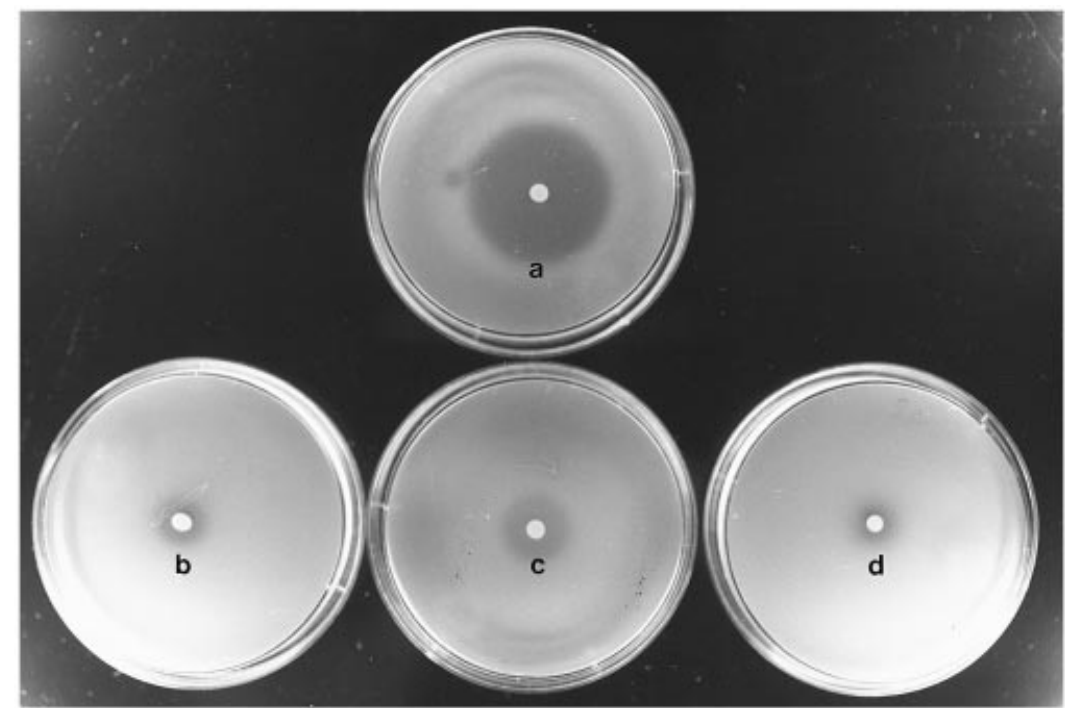

Fig. 4. Deferred inhibition tests with $C$. piscicola LV17A against C. piscicola LV17C (a) and C. piscicola LV17C containing pCF10 (b), pCF11 (c) and pCF13 (d).

piscicola LV17C containing pCF11 against both indicators was smaller than that produced by the positive control C. piscicola LV17A containing pCP49. The zone of inhibition produced by C. piscicola LV17C containing pCF10 was also markedly smaller than that of L. sakei DSM 20017 containing this construct when tested against the L. sakei DSM 20017 indicator strain (9 vs $17 \mathrm{~mm}$, respectively), whereas the inhibition zone produced by the L. sakei DSM 20017 containing pCF10 was comparable to that produced by the EntB-producing positive control Ent. faecalis ATCC 19433 containing pCMAP03. C. piscicola LV17C and L. sakei DSM 20017 containing either plasmid pCF12 or 13 were also tested for bacteriocin production against the indicators $L$. sakei DSM 20017 and C. piscicola LV17C. These clones expressed the same bacteriocins; however, the immunity genes were interchanged (see below). Similar-sized zones of inhibition were observed as described above for these clones containing plasmids pCF10 or 11.

\section{Expression of CbnA and EntB immunity genes and cross-immunity}

C. piscicola LV17C containing plasmid pCF10, 11 or 13, and L. sakei DSM 20017 containing plasmid pCF10, 11 or 12, were tested as indicators for homologous or heterologous expression of immunity and cross-immunity with the EntB-producer Ent. faecalis ATCC 19433 containing pCMAP03, or the CbnA producer C. piscicola LV17A. Ent. faecalis ATCC 19433 containing pCMAP03 was active against L. sakei DSM 20017. Clones of L. sakei containing pCF10, 11 or 12 were fully immune to EntB. C. piscicola LV17C containing pCF10, 11 or 13 when tested as indicators in the deferred inhibition assay with C. piscicola LV17A as producer exhibited partial immunity, as shown by small zones of inhibition surrounding the producer (Fig. 4). The largest zone of inhibition obtained with these clones was for $C$. piscicola LV17C containing the CbnA immunity gene on pCF11. However, when plasmids pCF10, 11 or 12 were contained in L. sakei DSM 20017 they imparted full immunity to CbnA (data not shown).

\section{DISCUSSION}

CbnA is one of three bacteriocins produced by the wildtype C. piscicola LV17 (Worobo et al., 1994). Initial characterization of CbnA defined it as a class II bacteriocin that is produced as a prebacteriocin con- 
taining an $\mathrm{N}$-terminal extension that is cleaved following a Gly(-2)-Gly(-1) processing site. Subsequently, Holck et al. (1994) purified the identical bacteriocin from C. piscicola LV61 and designated it piscicolin 61. These reports provided information only on the primary structure of the bacteriocin and cloning of the bacteriocin structural gene. To achieve full production of CbnA, it was necessary to include the $8.6 \mathrm{~kb}$ of DNA downstream of the structural gene. It was originally postulated that this region contained the dedicated secretion machinery for CbnA; however, the results of this study show that, in addition to the two genes encoding the transport proteins, there are three genes associated with regulated production of bacteriocin. When the ORFs associated with CbnA production were analysed, highest homology was found with the CbnB2 secretion and regulation proteins, although the bacteriocins CbnA and CbnB2 show little homology. Based on their similarity to regulation and secretion proteins of other bacteriocin systems and, in particular, the striking similarity to those of $\mathrm{CbnB} 2$, the protein products of $c b a X, c b a K$ and $c b a R$ were assumed to be involved in $\mathrm{CbnA}$ regulation and those of $c b a T$ and $c b a C$ in the transport of CbnA. Evidence that the product of $c b a X$ encodes an induction factor for $\mathrm{CbnA}$ regulation was obtained by chemical synthesis of mature CbaX devoid of the leader sequence and use of this peptide to induce CbnA production in a $\mathrm{Bac}^{-}$culture of C. piscicola LV17A. CbaX is produced intracellularly as a prepeptide containing a 17 amino acid leader peptide of the doubleglycine type, which is presumably removed by an $\mathrm{ABC}$ transporter during export from the cell. Bacteriocin production was induced at $10^{-11} \mathrm{M}$. Concentrations of extracellular signal molecules of Gram-positive bacteria are known to exert biological activity in the nanomolar range or below (Dunny \& Leonard, 1997; Nilsen et al., 1998).

Most class II bacteriocins have a dedicated immunity gene that immediately follows the structural gene in an operon-type arrangement, the product of which protects the cell from its own bacteriocin (Nes et al., 1996). This was not the case for CbnA. It resembles the case of EntB production from Ent. faecium BFE 900 and T136, in which the immunity gene was not found in an operon together with the bacteriocin structural gene, but was located immediately downstream of, and in opposite orientation to, the bacteriocin structural gene (Franz et al., 1999). For CbnA, orf +1 was initially thought to encode the CbnA immunity protein (Worobo et al., 1994); however, when a 700 bp StuI-HindIII fragment containing this ORF was cloned and used in heterologous expression tests, immunity to CbnA was not observed (data not shown). In addition, absence of this ORF in pCF04 did not result in loss of the partial immunity phenotype. The gene conferring partial immunity to CbnA was identified by making sequential deletions of the $3.1 \mathrm{~kb}$ fragment in pCF02. When this gene (cbiA) was amplified by PCR and cloned into $C$. piscicola LV17C, it conferred the same level of partial immunity to this homologous host.
It is not clear why $c b i A$ did not confer full immunity to C. piscicola LV17C, but a partial immunity phenotype has also been observed in other bacteriocin systems. Nisin immunity depends on the product of nisI, which is under common regulation with the nis $A$ structural gene (Kuipers et al., 1993). However, the nisE, nisF and nis G genes also are required for full immunity, and NisE and NisF show high homology to ABC transporter proteins (Siegers \& Entian, 1995). The cyclic peptide bacteriocin AS-48 produced by Ent. faecalis S-48 requires the product of the as-48D1 gene for immunity. In addition, the presence of the genes $a s-48 B, C 1$ and $D$ is required for full immunity (Martínez-Bueno et al., 1998). It was suggested that these genes encode subunits of an $\mathrm{ABC}$ transporter (As-48C1 and As-48D) as well as a protein (As-48B) involved with bacteriocin maturation (Martínez-Bueno et al., 1998). The ABC transporter protein involved with transport of lacticin 481 in Lactococcus lactis strains is assembled from three subunits that are encoded by the genes $l c t F, E$ and $G$. The presence of these three genes imparted full immunity to lacticin 481 (Rincé et al., 1997). Therefore, ABC transporter proteins also may have an immunity function in some bacteriocin systems. However, in the case of CbnA immunity, the association of transport proteins with immunity was considered unlikely. Only the Nterminal part of the putative $\mathrm{ABC}$ transporter of $\mathrm{CbnA}$ was present in plasmid pCF01. Yet, in homologous expression experiments, this plasmid conferred full immunity to CbnA.

The change from a full to a partial immunity phenotype occurred only in the absence of functional CbnA histidine kinase and response regulator genes, suggesting that production of $\mathrm{CbnA}$ immunity may be regulated. This is supported by similar observations that inactivation of regulatory genes decreases immunity. The presence of the response regulator gene nisR was required for nisin production and this gene was also shown to regulate nisin immunity (van der Meer et al., 1993). For the sakacin A system it was shown that inactivation of the histidine kinase or response regulator genes resulted in the loss of immunity (Axelsson \& Holck, 1995). For sakacin P, a frame-shift mutation in the histidine kinase gene also resulted in loss of immunity, while a deletion in the response regulator gene did not (Hühne et al., 1996). These results indicate that the immunity phenotype can be subject to regulation and that the partial immunity phenotype observed for CbnA immunity is probably a result of basal-level expression of the immunity gene. However, heterologous expression of cbiA in L. sakei DSM 20017 resulted in full immunity of this host to CbnA. A difference in expression levels or efficiency of this gene in these hosts may explain this observation compared with only partial immunity when cbiA was cloned in $C$. piscicola LV17C. The mechanism of regulation of immunity requires further study to explain the partial immunity phenotype observed here.

CbiA consists of 56 amino acids, which is two amino acids less than EniB. CbiA and EniB are very similar in 
that they are hydrophobic peptides which contain charged amino acids at the amino and carboxy ends (Fig. 3). Using the PepTool protein structure prediction software both peptides were predicted to form an $\alpha$ helix which may insert into the membrane. CbnA and EntB are Listeria-active bacteriocins, but they differ from other class II, especially class IIa bacteriocins, in that they do not contain a YGNGVXC consensus motif at the $\mathrm{N}$-terminus of the mature bacteriocin peptide (Worobo et al., 1994; Casaus et al., 1997; Franz et al., 1999). The immunity proteins of these bacteriocins and the mature bacteriocins have sequence similarity (30 and $45 \%$ identity, respectively) as shown in Fig. 3, and the immunity genes $c b i A$ and $e n i B$ can be interchanged to cross-protect against EntB and CbnA. This is the first report of successful interchange of immunity genes in bacteriocin systems. The exact mechanism(s) by which immunity proteins function is not clear. It was suggested that immunity protein for $\mathrm{CbnB} 2$ blocked the pore formed by bacteriocins from the cytoplasmic side (Quadri et al., 1995). Other immunity proteins, e.g. LafI and LciM (van Belkum et al., 1991; Allison \& Klaenhammer, 1996), were predicted to have transmembrane helices and therefore to be associated with the membrane. They may interact with the receptor for the bacteriocin and prevent binding of the bacteriocin to the membrane of the producer cell (Allison \& Klaenhammer, 1996). EniB and CbiA also have an $\alpha$-helical domain that may insert into the membrane and prevent bacteriocin binding. The homology observed between the mature $\mathrm{CbnA}$ and $\mathrm{EntB}$ and between their respective immunity proteins raises the question whether these bacteriocins should in future be considered as a novel class of bacteriocins.

\section{ACKNOWLEDGEMENTS}

These investigations were supported by the Natural Sciences and Engineering Research Council of Canada. C.M.A.P.F. gratefully acknowledges the financial assistance of a University of Alberta dissertation fellowship.

\section{REFERENCES}

Ahn, C. \& Stiles, M. E. (1990). Plasmid-associated bacteriocin production by a strain of Carnobacterium piscicola from meat. Appl Environ Microbiol 56, 2503-2510.

Ahn, C. \& Stiles, M. E. (1992). Mobilization and expression of bacteriocin plasmids from Carnobacterium piscicola isolated from meat. J Appl Bacteriol 73, 217-228.

Allison, G. E \& Klaenhammer, T. R. (1996). Functional analysis of the gene encoding immunity to lactacin F, lafI, and its use as a Lactobacillus-specific, food grade genetic marker. Appl Environ Microbiol 62, 4450-4460.

Anderssen, E. L., Diep, D. B., Nes, I. F., Eijsinck, V. G. H. \& NissenMeyer, J. (1998). Antagonistic activity of Lactobacillus plantarum C11: two new two-peptide bacteriocins, plantaricins EF and JK, and the induction factor plantaricin A. Appl Environ Microbiol 64, 2269-2272.

Axelsson, L. \& Holck, A. (1995). The genes involved in production of and immunity to sakacin A, a bacteriocin from Lactobacillus sake Lb706. J Bacteriol 177, 2125-2137.
Aymerich, T., Holo, H., Håvarstein, L. S., Hugas, M., Garriga, M. \& Nes, I. F. (1996). Biochemical and genetic characterization of EntA from Enterococcus faecium, a new antilisterial bacteriocin in the pediocin family of bacteriocins. Appl Environ Microbiol 62, 1676-1682.

van Belkum, M. J., Hayema, B. J., Jeeninga, R. E., Kok, J. \& Venema, G. (1991). Organization and nucleotide sequence of two lactococcal bacteriocin operons. Appl Environ Microbiol 57, 492-498.

van Belkum, M. J. \& Stiles, M. E. (1995). Molecular characterization of genes involved in the production of the bacteriocin leucocin A from Leuconostoc gelidum. Appl Environ Microbiol 61, 3573-3884.

Berthier, F., Zagorec, M., Champomier-Vergès, M., Ehrlich, S. D. \& Morel-Deville, F. (1996). Efficient transformation of Lactobacillus sake by electroporation. Microbiology 142, 1273-1279.

Brurberg, M. B., Nes, I. F. \& Eijsinck, V. G. H. (1997). Pheromoneinduced production of antimicrobial peptides in Lactobacillus. Mol Microbiol 26, 347-360.

Casadaban, M. C. \& Cohen, S. N. (1980). Analysis of gene control signals by DNA fusion and cloning in Escherichia coli. J Mol Biol 138, 179-207.

Casaus, P., Nilsen, T., Cintas, L. M., Nes, I. F., Hernández, P. E. \& Holo, H. (1997). Enterocin B, a new bacteriocin from Enterococcus faecium T136 which can act synergistically with enterocin A. Microbiology 143, 2287-2294.

Chung, C. T., Niemela, S. L. \& Miller, R. H. (1989). One-step preparation of competent Escherichia coli: transformation and storage of bacterial cells in the same solution. Proc Natl Acad Sci USA 86, 2172-2175.

Diep, D. B., Håvarstein, L. S. \& Nes, I. F. (1995). A bacteriocin-like peptide induces bacteriocin synthesis in Lactobacillus plantarum C11. Mol Microbiol 18, 631-639.

Diep, D. B., Håvarstein, L. S. \& Nes, I. F. (1996). Characterization of the locus responsible for the bacteriocin production in Lactobacillus plantarum C11. J Bacteriol 178, 4472-4483.

Dunny, G. M. \& Leonard, B. A. B. (1997). Cell-cell communication in gram-positive bacteria. Annu Rev Microbiol 51, 527-564.

Eijsink, V. G. H., Skeie, M., Middelhoven, P. H., Brurberg, M. B. \& Nes, I. F. (1998). Comparative studies of class Ila bacteriocins of lactic acid bacteria. Appl Environ Microbiol 64, 3275-3281.

Franz, C. M. A. P., Worobo, R. W., Quadri, L. E. N., Schillinger, U., Holzapfel, W. H., Vederas, J. C. \& Stiles, M. E. (1999). Atypical genetic locus associated with constitutive production of enterocin B by Enterococcus faecium BFE 900. Appl Environ Microbiol 65, 2170-2178.

van de Guchte, M., van der Vossen, J. M. B. M., Kok, J. \& Venema, G. (1989). Construction of a lactococcal expression vector: expression of hen egg white lysozyme in Lactococcus lactis subsp. lactis. Appl Environ Microbiol 55, 224-228.

Holck, A., Axelsson, L. \& Schillinger, U. (1994). Purification and cloning of piscicolin 61, a bacteriocin from Carnobacterium piscicola LV61. Curr Microbiol 29, 63-68.

Hühne, K., Axelsson, L., Holck, A. \& Kröckel, L. (1996). Analysis of the sakacin P gene cluster from Lactobacillus sake Lb674 and its expression in sakacin-negative Lb. sake strains. Microbiology 142, 1437-1448.

Jewell, B. \& Collins-Thompson, D. L. (1989). Characterization of chloramphenicol resistance in Lactobacillus plantarum caTC2. Curr Microbiol 19, 343-346. 
Klaenhammer, T. R. (1993). Genetics of bacteriocins produced by lactic acid bacteria. FEMS Microbiol Rev 12, 39-86.

Kuipers, O. P., Beerthuysen, M. M., Siezen, R. J. \& de Vos, W. M. (1993). Characterization of nisin gene cluster nis ABTCIPR of Lactococcus lactis : requirement of expression of nis $A$ and nisI for producer immunity. Eur J Biochem 216, 281-291.

McCormick, J. K., Worobo, R. W. \& Stiles, M. E. (1996). Expression of the antimicrobial peptide carnobacteriocin B2 by a signal peptide-dependent general secretory pathway. Appl Environ Microbiol 62, 4095-4099.

McCormick, J. K., Poon, A., Sailer, M., Gao, Y., Roy, K. L., McMullen, L. M., Vederas, J. C., Stiles, M. E. \& van Belkum, M. J. (1998). Genetic characterization and heterologous expression of brochocin-c, an antibotulinal, two-peptide bacteriocin produced by Brochothrix campestris ATCC 43754. Appl Environ Microbiol 64, 4757-4766.

Martínez-Bueno, M., Valdivia, E., Gálves, A., Coyette, J. \& Maqueda, M. (1998). Analysis of the gene cluster involved in production and immunity of the peptide antibiotic AS-48 in Enterococcus faecalis. Mol Microbiol 27, 347-358.

van der Meer, J. P., Polman, J., Beerthyuzen, M. M., Siezen, R. J., Kuipers, O. P. \& de Vos, W. M. (1993). Characterization of Lactococcus lactis nisin A operon genes nisP, encoding a subtilisin-like serine protease involved in precursor processing, and nisR, encoding a regulatory protein involved in nisin biosynthesis. J Bacteriol 175, 2578-2588.

Nes, I. F., Diep, D. B., Håvarstein, L. S., Brurberg, M. B., Eijsinck, V. \& Holo, H. (1996). Biosynthesis of bacteriocins in lactic acid bacteria. Antonie Leeuwenhoek 70, 113-128.

Nilsen, T., Nes, I. F. \& Holo, H. (1998). An exported inducer peptide regulates bacteriocin-production in Enterococcus faecium CTC492. J Bacteriol 180, 1848-1854.

Nissen-Meyer, J., Holo, H., Håvarstein, L. S., Sletten, K. \& Nes, I. F. (1992). A novel lactococcal bacteriocin whose activity depends on the complementary action of two peptides. J Bacteriol 174, 5686-5692.

O'Keeffe, T., Hill, C. \& Ross, R. P. (1999). Characterization and heterologous expression of the genes encoding enterocin A production, immunity and regulation in Enterococcus faecium DPC1146. Appl Environ Microbiol 65, 1506-1515.

Quadri, L. E. N., Sailer, M., Roy, K. L., Vederas, J. C. \& Stiles, M. E. (1994). Chemical and genetic characterization of bacteriocins produced by Carnobacterium piscicola LV17B. J Biol Chem 269, 12204-12211.
Quadri, L. E. N., Sailer, M., Terebiznik, M. R., Roy, K. L., Vederas, J. C. \& Stiles, M. E. (1995). Characterization of the protein conferring immunity to the antimicrobial peptide carnobacteriocin B2 and expression of carnobacteriocins B2 and BM1. J Bacteriol 177, 1144-1151.

Quadri, L. E. N., Kleerebezem, M., Kuipers, O. P., de Vos, W. M., Roy, K. L., Vederas, J. C. \& Stiles, M. E. (1997). Characterization of a locus from Carnobacterium piscicola LV17B involved in bacteriocin production and immunity: evidence for global inducer-mediated transcriptional regulation. J Bacteriol 179, 6163-6171.

Rincé, A., Dufour, A., Uguen, P., Le Pennec, J.-P. \& Haras, D. (1997). Characterization of the lacticin 481 operon: the Lactococcus lactis genes $l c t F, l c t E$, and $l c t G$ encode a putative ABC transporter involved in bacteriocin immunity. Appl Environ Microbiol 63, 4252-4260.

Sambrook, J., Fritsch, E. F. \& Maniatis, T. (1989). Molecular Cloning: a Laboratory Manual, 2nd edn. Cold Spring Harbor, NY : Cold Spring Harbor Laboratory.

Siegers, K. \& Entian, K.-D. (1995). Genes involved in immunity to the lantibiotic nisin produced by Lactococcus lactis 6F3. Appl Environ Microbiol 61, 1082-1089.

Stephens, S. K., Floriano, B., Cathcart, D. P., Bayley, S. A., Witt, V. F., Jiménez Díaz, R., Warner, P. J. \& Ruiz-Barba, J. L. (1998). Molecular analysis of the locus responsible for production of plantaricin S, a two-peptide bacteriocin produced by Lactobacillus plantarum LPCO10. Appl Environ Microbiol 64, 1871-1877.

Vieira, J. \& Messing, J. (1982). The pUC plasmids, an M13mp7derived system for insertion mutagenesis and sequencing with synthetic universal primers. Gene 19, 259-268.

Worobo, R. W. (1996). Characterization of two bacteriocins and a food grade plasmid from carnobacteria. $\mathrm{PhD}$ thesis, University of Alberta.

Worobo, R. W., Henkel, T., Sailer, M., Roy, K. L., Vederas, J. C. \& Stiles, M. E. (1994). Characteristics and genetic determinant of a hydrophobic peptide bacteriocin, carnobacteriocin A, produced by Carnobacterium piscicola LV17A. Microbiology 140, 517-526.

Worobo, R. W., van Belkum, M. J., Sailer, M., Roy, K. L., Vederas, J. C. \& Stiles, M. E. (1995). A signal peptide secretion-dependent bacteriocin from Carnobacterium divergens. J Bacteriol 177, 3143-3149.

Received 2 September 1999; revised 29 November 1999; accepted 9 December 1999. 